\title{
Assessment of Some Bacteriological Quality of Streams of Upper Awash River, Central Ethiopia
}

\author{
Anania Hailu \\ Ethiopian Environment and Forest Research institute, Addis Ababa
}

\begin{abstract}
Supply of safe and adequate drinking water is very essential for the health of human beings. But water safety and sanitations in the developing countries has been a serious problem threatening the community of these nations. The major objective of this article is to communicate the microbial quality of water of streams of upper Awash River. The indicator microbial quality of the water samples from streams of upper Awash River was analyzed using membrane filtration techniques, while heterotrophic bacteria, Bacillus spp and Staphylococcus aureus count were done by using specific isolation techniques for the particular organisms. From the five different sampling sites site 1 and 4 showed highest total coliform count ranging from 17300 to $22000 \mathrm{cfu} / 100 \mathrm{ml}$. Escherichia coli count ranged from 200to $11300 \mathrm{cfu} / 100 \mathrm{ml}$; Entrococcus count ranged from 178to $2300 \mathrm{cfu} / 100 \mathrm{ml}$; Clostridium perfringes ranged from 66 - to $201 \mathrm{cfu} / 100 \mathrm{ml}$. Hetrotrophic plate count ranged from $350-2380 \mathrm{cfu} / 100 \mathrm{ml}$. Bacillus spp count ranged from $320-990 \mathrm{cfu} / 100 \mathrm{ml}$. Staphylococcus aureus count ranged $300-1950 \mathrm{cfu} / 100 \mathrm{ml}$. The result of this investigation indicated that all the indicator microorganisms and other bacterial species were found to be above the minimum number of the specific group of the organisms showing that the water of streams of upper Awash river is highly exposed to certain pollution and it need some means of purification before it used for the intended purposes.
\end{abstract}

Keywords/phrases: bacteriological; indicator microorganisms, Streams; water quality

DOI: $10.7176 /$ JNSR/10-9-01

Publication date:May $31^{\text {st }} 2020$

\section{Introduction}

Next to oxygen water is the most important substances for human existence (White,1969). It is an essential resource which sustains agriculture, allow aquatic life, supports industry, produce hydroelectric power, permit aquatic transport, ensures personal hygiene, maintain clean environment, and it used for sport as well as for recreations (Ministry of Water Resources, 1997, Falkenmark, 1982). In addition, water is very essential for washing, cooking, bathing, food processing, brewing, beverage bott lingetc. (Oesterholt et al., 2007). This therefore necessitates a constant supply of potable water to all human communities but most of the area slacks good improved water supply especially in developing countries. However, there is a lot of time,effort, and money that is required or invested so as to find a suitable source of water supply (Oester holt et al., 2007).Unfortunately, such water sources are scarce and even when they are available; they are seldom safe for consumption. There is therefore a great need for water to be treated effectively in order to make it potable and safe for humans. Water quality can have a major impact on both individuals and communities health. According to the World Health Organization, about 1.4 million children die from diarrhea due unsafe drinking water (WHO; 2011). Therefore, for good human health, it is important to ensure that drinking water is well treated before consumption (Massoud et al., 2010).

Consumption of contaminated drinking water was associated with 80 percent of disease and one third of death in developing countries (Mellor et al., 2013;Echoruet al., 2015). Therefore, an essential basic requirement for health protection is to provide the public with safe and adequate drinking water (WHO 2011).

In all urban areas in the developed countries, supply of adequately treated water is done by municipal authorities (Howard and Bartram 2005). For the case of developing countries, there is little or no access to such treated water and therefore it is often very difficult or even impossible to get portable water. This is because of inadequate funds available to the municipal for appropriate treatment and supply of water and this being so, a large percentage of people in developing countries have to rely on their own personal efforts in order to get safe drinking water (Howard and Bartram 2005).

Water for consumption is supposed to be free from microbial contamination but it's not obvious that all microorganisms present in water are harmful. The most dangerous microorganisms are the coliforms which are part of the normal flora of the gut of warm blooded animals. The presence of contamination with any of these organisms and others can be tested using various indicators. However the development of such indicators has never been such an easy job and up to date, there still remains considerable arguments about the best indicators for testing microbial contamination (Jeonget al., 2011).

Besides, sustainable social and economic development is largely dependent on water resources. However, securing water (quality and quantity) to satisfy the needs of the humans and ecosystems is one of the primary issues challenging the $21^{\text {st }}$ century(Amangabara and Ejenma, 2012). Compounding the problem is the fact that water quality is one of the most sensitive issues worldwide, potentially influenced by many natural and 
anthropogenic factors. Theses includes: sources of water, the degree of its evaporation, types of rocks and minerals it has encounter (i.e. geology and mineralogy of the water shade), geological processes within the aquifer, velocity and direction of water movement, and the time it has been in contact with reactive minerals ( Freeze and Cherry, 1979). It is also affected by external pollution agencies such as effluents from agricultural return flows, industrial and domestic activities (Srinvasa moothy et al., 2012).

It is well known that the quality and safety of the drinking water continues to be an important publichealth issue, because its contamination has been frequently described as responsible for the transmission of infectious diseases that have caused serious illness and associated mortality worldwide (Hrudey and Hrudey 2007, Marshall, et al. 2006, Jones etal., 2007, Peace and Mazunder, 2006)

The World Health Organization estimated that up to $80 \%$ of all sicknesses and diseasesof world is caused by inadequate sanitation, polluted water or unavailability of water. InEthiopia over $60 \%$ of the communicable diseases are due to poor environmental health conditions arising from unsafe and inadequate water supply and poor hygienic and sanitation practices (WHO, 2004). Several studies have confirmed that water related diseases not only remain a leading cause of morbidity and mortality worldwide but that the spectrum of diseases is expanding and the incidence of many water-related microbial disease is increasing (WHO, 2003). Diarrhea remains a major killer in children and it is estimated that $80 \%$ of all illness in developing countries is related to water and sanitation; and that $15 \%$ of all child deaths under the age of 5 years in developing countries results from diarrheal diseases (WHO, 2003).

In rural areas and villages of Ethiopia, water for human consumption, drinking, washing (bathing,laundry), for preparation of food etc, is obtained from rivers, streams, shallow wells, spring lakes, ponds, and rainfall. Unless water is made safe or treated for human consumption, it may behazardous to health and transmit diseases. The main contaminants of these water sources arehuman excreta, animal waste and effluent because of open field defecation practices. The aim of this article is to communicate the microbial quality of water of upper Awash river, Central Ethiopia

\section{Materials and methods}

Description of Study area

This investigation was carried out on streams of upper Awash River in Chilimo forest around Ginchi town which is located in West Shoa Zone, Oromia Regional State. Ginchi is located seventy five kilometers west of Addis Ababa on the Addis Ababa-Nekamte road. The Woreda has a total area of 109,729 ha with altitudinal range from 2000-3200 meter above sea level. Based on the (CSA,2007) population census; the total population of Dandi District is estimated at 256,896. Its favorable climatic condition for both crops and livestock production has been attributed for more population in the Woreda. This Woreda is well known for its rich water resources among which Awash River basin and Lake Dandi are the most important natural resources in the distinct. Lake Dandi is one of the highland lakes found in the district, and has a high tourist potential. The Awash River basin is well known and it covers a catchment area of $110,000 \mathrm{~km} 2$ and serves as home for 10.5 million inhabitants. The river originates from a high plateau near Ginchi town, and flows along the rift valley into the Afar triangle and ends in Saline Lake Abbe.

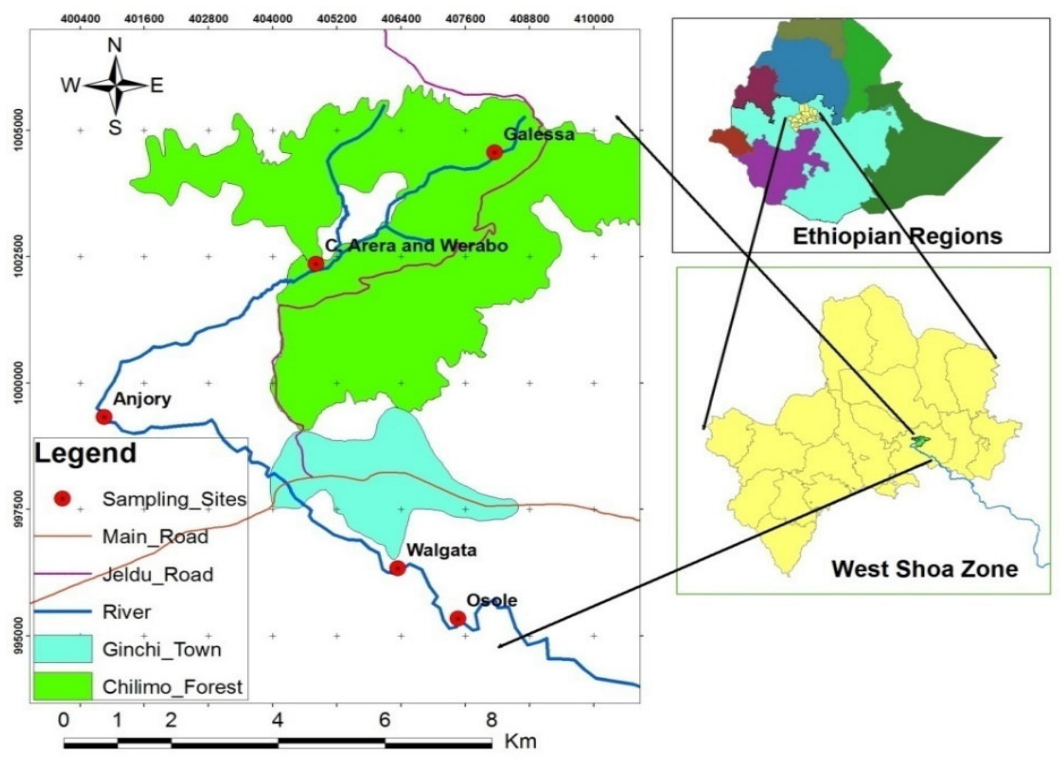

Figure1: Site map of the study area 


\section{Sampling sites and sample collection}

Representative sampling sites were selected by purposive sampling method and each sample was taken directly from the streams of upper Awash River in two weeks once, and total of six times from the month of December 2017 to March 2018.

A preliminary survey was conducted in the November 2017 together with some general information about the topography, physical characteristics of the area and human activities along the course of streams of upper Awash River. Sampling sites were selected based on their exposure to organic wastes and various human activities that pollute the water.The topographic features and habitat structure were also taken in to consideration while selecting the sampling sites. Accordingly, five sampling sites were selected along the longitudinal zonation of the upper Awash River and designated as; sampling site one at the middle of chilimo forest called:Galesa site (Aw1), the second site is Arera (Aw2), which is two Km far from site Aw1 in the forest,Anjori site (Aw3), after it leaves the chilimo forest $11 \mathrm{~km}$ far from Aw2,Wamurasako site or welgeta (Aw4), which is $10 \mathrm{~km}$ far from Aw3 and the fifth site is Osole site (Aw5)which is two km far from Aw4.

\section{Water sample collection}

The water samples from the study area were collected inthe brown bottle which is $500 \mathrm{ml}$ capacity. The bottles were pre sterilized by autoclaving. Double composite samples were collected from each study site. The collected water samples were immediately put in the ice box in order to avoid the loss of the microorganisms though injury and transported to Biology Laboratory department of Biology College Natural and Computational sciences, Ambo University and processed with $8 \mathrm{hrs}$ for the indicator microbial load.

\section{Water samples processing and incubation}

The water samples brought to the laboratory were filtered through filter membrane. sample was filtered using 0.45 $\mathrm{mm}$ pore size, $47 \mathrm{~mm}$ diameter filter membrane as described by NOM-127-SSA1-1994and APHA, Whatman cellulose nitrate membrane filters (Sartorius, Vienna, Austria) and were put in triplicate in the selective isolation and enumeration purposes as described below.

\section{Total coliform and E.coli}

Escherichia coli detection with chromocult coliform agar (www.himedialabs.com).Recently, application of defined substrate medium technology with particular selective growth conditions and the simultaneous detection of B-D-galactosidase and B-D-glucuronidase activity have become widespread tools for the detection of $E$. coli in water and wastewater (Brenner, 1993, 1996; clark.et al, 1991; rice et al, 1990; Venkateswaran.et al, 1996).For simultaneous enumeration of Total coliform and E. coli, filters were placed onto CCA plates and incubated at $37^{\circ} \mathrm{C}$ for $24 \mathrm{hrs}$, thetotal coliforms and E. Coli isolates on CCA were enumerated. Blue, blue black or violet colonies on plates were classified as E.coli, red colonies on plate were total coliform (Sartorius, Vienna, Austria).

\section{Enterococcus}

M-enterococcus agar base was used for enterococcus (www.himedialabs.com).mediawas amended to select against possible background bacteria by the addition of cefsulodin ( $5 \mathrm{mg} /$ liter; Sigma, Vienna, Austria), while those for enterococcus were placed on m-enterococcus agar base plates, and incubatedat $37^{\circ} \mathrm{C}$ for $48 \mathrm{hrs}$. Red colonies on M-enterococcus agar base were classified as enterococcus (Sartorius, Vienna, Austria).

\section{Clostridium perfringes}

Fluorocult-tryptose sulfite cycloserine (F-TSC)(Merck, Darmstadt, Germany) was used to isolate Clostridium perfringes (www.himedialabs.com) supplement $(0.4 \mathrm{~g} /$ liter; Merck)was added on the media to against possible background bacteria, To select for spores of $\mathrm{CP}$, samples were first preheated at $75^{\circ} \mathrm{C}$ for 15 min in a water bath before filtration. After filtration, the membrane filters were placed on F-TSC agar plates, put in an anaerobic jar containing Anaerocult Anaerobic system (Merck), and incubated at $44^{\circ} \mathrm{C}$ for $24 \mathrm{~h}$ in a dry incubator), while black colonies growing on F-TSC plateswere Clostridium perfringes (Sartorius, Vienna, Austria).

\section{Heterotrophic plate Count}

One $\mathrm{ml}$ of water sample was transferred aseptically to $9 \mathrm{ml}$ of distilled sterilized water and homogenized by Vortex machine ( Biocote ) and a serial dilutions of $\left(10^{-1}, 10^{-2}, 10^{-3}, 10^{-4}, 10^{-5}\right)$ was made by taking $1 \mathrm{ml}$ from homogenized sample and adding to sterile test tube containing $9 \mathrm{ml}$ sterile distilled water and mixed properly by vortex machine. $0.1 \mathrm{ml}$ of each dilution was spread plated on a Plate Count Agar (PCA) medium and incubated at $28^{\circ} \mathrm{Cfor} 48$ hours. All colonies that are $0.5 \mathrm{~mm}$ or larger in diameter were counted using digital colony counter. The number $(\mathrm{N})$ of $\mathrm{CFU} / \mathrm{ml}$ of water sample was calculated (Robertet al, 2003).

\section{Staphylococcus aurous}

One $\mathrm{ml}$ of sample water was transferred aseptically to $9 \mathrm{ml}$ of distilled sterilized water and homogenized by Vortex machine ( Biocote ) and a serial of dilutions $\left(10^{-1}, 10^{-2}, 10^{-3}, 10^{-4}, 10^{-5}\right)$ was made by taking $1 \mathrm{ml}$ from homogenized sample and adding to sterile test tube containing $9 \mathrm{ml}$ sterile distilled water and mixed properly by vortex machine then $0.1 \mathrm{ml}$ of the dilutions 1:10, was spread plated on Manitol Salt Agar (MSA) and incubated at 37 $7^{\circ}$ for 2448 hour. Golden yellow and Orange colonies were counted using digital colony counter and the colony was confirmed by staining and recorded as a result. 


\section{Bacillus}

In order to count the Bacillus spps (aerobic spore formers) in the water samples taken from the streams of upper awash river the serial diluted water samples were first preheated at $75^{\circ} \mathrm{C}$ for $15 \mathrm{~min}$ in a water bath before inoculation in order to kill all the vegetative cells and $0.1 \mathrm{ml}$ of the heated and cooled water samples was spread plated on the nutrient agar and incubated at $32^{\circ} \mathrm{C}$ for $18-24$ hours. After incubation the colony formed on the nutrient agar was confirmed by gram staining and counted as Bacillus spps (aerobic endospore formers).

\section{Gram staining}

\section{Bacillus}

The slide was placed on the staining rack then a one colony of bacteria was placed on the slide and flood with malachite green then the bottom of the slide was heated with flame then allowed for 5 minute and washed with water finally the slide was fully covered with safranim and rinsed with tap water and air dry then the bacteria was examined under oil immersion

\section{Statistical analysis}

All the statistical analyses were done with the Statistical Package for the Social Sciences, version 24.The significance of differences in bacterial counts and physicochemical parameters of water samples from the stream of upper Awash River between sampling sites were determined by one-way analysis of variance (ANOVA). P value of $<0.05$ was considered significant.

\section{Results}

\section{Total coliforms}

In this investigations, the count of total coliform between the sampling rounds shows significant variation $(\mathrm{P}<0.05)$. The count of total coliform for three month from five sampling sites indicate that sampling sites Aw1 and Aw4 showed higher total coliform ranged from $1780 \mathrm{CFU} / 100 \mathrm{ml}$ to $17300 \mathrm{CFU} / 100 \mathrm{ml}$ and $2050 \mathrm{CFU} / 100 \mathrm{ml}$ to 22000 $\mathrm{CFU} / 100 \mathrm{ml}$ respectively. The minimum total coliform mean value was observed from the water sample taken from site Aw3 which was ranged between $12200 \mathrm{CFU} / 100 \mathrm{ml}$ to $1440 \mathrm{CFU} / 100 \mathrm{ml}$ (Table 1).

Table 1;Total coliform count $\mathrm{CFU} / 100 \mathrm{ml}$

\begin{tabular}{|l|l|l|l|l|l|l|l|}
\hline Organism & Site & $\begin{array}{c}\text { CFU/100ml } \\
\text { Round 1 }\end{array}$ & $\begin{array}{c}\text { CFU/100 } \\
\text { ml Round } \\
2\end{array}$ & $\begin{array}{c}\text { CFU/100ml } \\
\text { Round 3 }\end{array}$ & $\begin{array}{c}\text { CFU/100ml } \\
\text { Round 4 }\end{array}$ & $\begin{array}{c}\text { CFU/100ml } \\
\text { Round 5 }\end{array}$ & $\begin{array}{c}\text { CFU/100ml } \\
\text { Round 6 }\end{array}$ \\
\hline \multirow{5}{*}{ TC } & Aw1 & $1780^{\mathrm{a}}$ & $1600^{\mathrm{c}}$ & $2670^{\mathrm{c}}$ & $17300^{\mathrm{d}}$ & $15900^{\mathrm{b}}$ & $11000^{\mathrm{a}}$ \\
\cline { 2 - 8 } & Aw2 & $1980^{\mathrm{c}}$ & $1280^{\mathrm{b}}$ & $2590^{\mathrm{c}}$ & $10300^{\mathrm{c}}$ & $16800^{\mathrm{d}}$ & $13600^{\mathrm{c}}$ \\
\cline { 2 - 8 } & Aw3 & $2210^{\mathrm{d}}$ & $2290^{\mathrm{e}}$ & $1440^{\mathrm{a}}$ & $3200^{\mathrm{a}}$ & $6600^{\mathrm{a}}$ & $12200^{\mathrm{b}}$ \\
\cline { 2 - 8 } & Aw4 & $2490^{\mathrm{e}}$ & $2050^{\mathrm{d}}$ & $2650^{\mathrm{c}}$ & $20900^{\mathrm{e}}$ & $19500^{\mathrm{e}}$ & $22000^{\mathrm{e}}$ \\
\cline { 2 - 8 } & Aw5 & $1900^{\mathrm{b}}$ & $1010^{\mathrm{a}}$ & $2350^{\mathrm{b}}$ & $8700^{\mathrm{b}}$ & $16400^{\mathrm{c}}$ & $18300^{\mathrm{d}}$ \\
\hline
\end{tabular}

Figures followed with the same superscript letter are not significantly different from each other $(\mathrm{p} \geq 0.05)$

\section{Escherichia coli}

The result obtained from laboratory analysis of E.coli of water samples from streams of upper Awash River during the six round of sampling showed mean values ranged from $200 \mathrm{CFU} / \mathrm{ml}$ to $11300 \mathrm{CFU} \mathrm{ml} / 100 \mathrm{ml}$.In the six sampling round, round one has highest load and round two has the lowest load. E.coli count was highest in the water sample taken from Aw3:11300 CFU/100ml and lowest in the water sample taken from site AW5: 200 $\mathrm{CFU} / 100 \mathrm{ml}$. There was no significant difference between impacted sites $(\mathrm{p}>0.05)$ from the count of ofE.coliin as compared to water sample taken from five different sampling sites

Table 2; Escherichia coli count CFU/100ml

\begin{tabular}{|l|l|l|l|l|l|l|l|}
\hline $\begin{array}{l}\text { Organ } \\
\text { ism }\end{array}$ & Site & $\begin{array}{l}\text { CFU/10 } \\
\text { 0ml } \\
\text { Round 1 }\end{array}$ & $\begin{array}{l}\text { CFU/100ml } \\
\text { Round 2 }\end{array}$ & $\begin{array}{l}\text { CFU/100ml } \\
\text { Round 3 }\end{array}$ & $\begin{array}{l}\text { CFU/100ml } \\
\text { Round 4 }\end{array}$ & $\begin{array}{l}\text { CFU/100ml } \\
\text { Round 5 }\end{array}$ & $\begin{array}{l}\text { CFU/100ml } \\
\text { Round 6 }\end{array}$ \\
\hline \multirow{4}{*}{ E.coli } & Aw1 & $290^{\mathrm{a}}$ & $260 \mathrm{~b}$ & $230^{\mathrm{a}}$ & $380^{\mathrm{b}}$ & $670^{\mathrm{b}}$ & $1980^{\mathrm{b}}$ \\
\cline { 2 - 8 } & Aw2 & $360^{\mathrm{b}}$ & $200^{\mathrm{a}}$ & $610^{\mathrm{c}}$ & $690^{\mathrm{c}}$ & $790^{\mathrm{c}}$ & $3690^{\mathrm{e}}$ \\
\cline { 2 - 8 } & Aw3 & $11300^{\mathrm{d}}$ & $310^{\mathrm{c}}$ & $210^{\mathrm{a}}$ & $210^{\mathrm{a}}$ & $220^{\mathrm{a}}$ & $2890^{\mathrm{c}}$ \\
\cline { 2 - 8 } & Aw4 & $990^{\mathrm{c}}$ & $810^{\mathrm{d}}$ & $850^{\mathrm{d}}$ & $730^{\mathrm{c}}$ & $870^{\mathrm{d}}$ & $3320^{\mathrm{d}}$ \\
\cline { 2 - 8 } & Aw5 & $300^{\mathrm{a}}$ & $200^{\mathrm{a}}$ & $450^{\mathrm{b}}$ & $350^{\mathrm{b}}$ & $700^{\mathrm{b}}$ & $510^{\mathrm{a}}$ \\
\hline
\end{tabular}

Figures followed with the same superscript letter are not significantly different from each other $(\mathrm{p} \geq 0.05)$

\section{Enterococcus}

In this study, the highest enterococcus load was observed in round six and the lowest enterococcus load was observed in round one. Highest Enterococcus count was observed in the water samples taken from the site 4(Aw4); followed by the water sample taken from site 1 (Aw1), and the mean values were between $178 \mathrm{CFU} / 100 \mathrm{ml}$ to $2300 \mathrm{CFU} / 100 \mathrm{ml}$ and $218 \mathrm{CFU} / 100 \mathrm{ml}$ to $2270 \mathrm{CFU} / 100 \mathrm{ml}$ respectively. The lowest Enterococcus count was observed in the water samples taken from site 5 (Aw5) and the mean value was ranged from 96CFU/100ml to 710 
CFU/100ml. Over all there were significant differences between impacted sites $(\mathrm{p}<0.05)$ and the less impacted site from the point of view of Enterococcus count (Table 3).

Table 3 :Enterococcus count $\mathrm{CFU} / 100 \mathrm{ml}$

\begin{tabular}{|l|l|l|l|l|l|l|l|}
\hline $\begin{array}{l}\text { Organis } \\
\mathrm{m}\end{array}$ & Site & $\begin{array}{l}\text { CFU/10 } \\
\text { 0ml } \\
\text { Round 1 }\end{array}$ & $\begin{array}{l}\text { CFU/100ml } \\
\text { Round 2 }\end{array}$ & $\begin{array}{l}\text { CFU/100ml } \\
\text { Round 3 }\end{array}$ & $\begin{array}{l}\text { CFU/100ml } \\
\text { Round 4 }\end{array}$ & $\begin{array}{l}\text { CFU/100ML } \\
\text { Round 5 }\end{array}$ & $\begin{array}{l}\text { CFU/100ml } \\
\text { Round 6 }\end{array}$ \\
\hline \multirow{4}{*}{$\begin{array}{l}\text { Enteroc } \\
\text { occus }\end{array}$} & Aw1 & $218^{\mathrm{c}}$ & $248^{\mathrm{c}}$ & $332^{\mathrm{c}}$ & $440^{\mathrm{c}}$ & $1070^{\mathrm{b}}$ & $2270^{\mathrm{d}}$ \\
\cline { 2 - 9 } & Aw2 & $144^{\mathrm{b}}$ & $112^{\mathrm{a}}$ & $266^{\mathrm{b}}$ & $358^{\mathrm{b}}$ & $1180^{\mathrm{c}}$ & $2030^{\mathrm{c}}$ \\
\cline { 2 - 8 } & Aw3 & $346^{\mathrm{d}}$ & $330^{\mathrm{d}}$ & $126^{\mathrm{a}}$ & $158^{\mathrm{a}}$ & $134^{\mathrm{a}}$ & $1960^{\mathrm{b}}$ \\
\cline { 2 - 8 } & Aw4 & $178^{\mathrm{bc}}$ & $406^{\mathrm{e}}$ & $480^{\mathrm{d}}$ & $402^{\mathrm{bc}}$ & $1280^{\mathrm{d}}$ & $2300^{\mathrm{d}}$ \\
\cline { 2 - 8 } & Aw5 & $96^{\mathrm{a}}$ & $186^{\mathrm{b}}$ & $254^{\mathrm{b}}$ & $120^{\mathrm{a}}$ & $100^{\mathrm{a}}$ & $710^{\mathrm{a}}$ \\
\hline
\end{tabular}

\section{Clostridium perfringes}

The highest Clostridium perfringes count was observed in round six and the lowest Clostridium perfringes was observed in round two. The highest Clostridium perfringes was detected from the water sample taken from site 2(Aw2) which was ranged between $201 \mathrm{CFU} / 100 \mathrm{ml}$ to $66 \mathrm{CFU} / 100 \mathrm{ml}$ and the lowest Clostridium perfringes counted was observed in water samples taken from site(Aw3) which was ranged $23 \mathrm{CFU} / 100 \mathrm{ml}$ to $95 \mathrm{CFU} / 100 \mathrm{ml}$. There was no significant difference between the reference site and impacted sites $(\mathrm{p} \geq 0.05)$ for the number of Clostridium perfringes was count.

Table: 4. Clostridium perfringes count $\mathrm{CFU} / 100 \mathrm{ml}$

\begin{tabular}{|l|l|l|l|l|l|l|l|}
\hline $\begin{array}{l}\text { Organi } \\
\text { sm }\end{array}$ & Site & $\begin{array}{l}\text { CFU/100 } \\
\text { ml Round } \\
1\end{array}$ & $\begin{array}{l}\text { CFU/100ml } \\
\text { Round 2 }\end{array}$ & $\begin{array}{l}\text { CFU/100ml } \\
\text { Round 3 }\end{array}$ & $\begin{array}{l}\text { CFU/100ml } \\
\text { Round 4 }\end{array}$ & $\begin{array}{l}\text { CFU/100ml } \\
\text { Round 5 }\end{array}$ & $\begin{array}{l}\text { CFU/100ml } \\
\text { Round 6 }\end{array}$ \\
\hline \multirow{4}{*}{$\begin{array}{l}\text { Clostri } \\
\text { dium }\end{array}$} & Aw1 & $140^{\mathrm{b}}$ & $48^{\mathrm{a}}$ & $115^{\mathrm{b}}$ & $58^{\mathrm{a}}$ & $84^{\mathrm{b}}$ & $198^{\mathrm{b}}$ \\
\cline { 2 - 8 } & Aw2 & $109^{\mathrm{b}}$ & $66^{\mathrm{ab}}$ & $56^{\mathrm{a}}$ & $180^{\mathrm{c}}$ & $201^{\mathrm{c}}$ & $156^{\mathrm{b}}$ \\
\cline { 2 - 8 } & Aw3 & $61^{\mathrm{a}}$ & $61^{\mathrm{ab}}$ & $95^{\mathrm{ab}}$ & $48^{\mathrm{a}}$ & $23^{\mathrm{a}}$ & $56^{\mathrm{a}}$ \\
\cline { 2 - 8 } & Aw4 & $150^{\mathrm{b}}$ & $88^{\mathrm{ab}}$ & $109^{\mathrm{b}}$ & $107^{\mathrm{b}}$ & $53^{\mathrm{ab}}$ & $168^{\mathrm{b}}$ \\
\cline { 2 - 8 } & Aw5 & $119^{\mathrm{b}}$ & $104^{\mathrm{b}}$ & $51^{\mathrm{a}}$ & $45^{\mathrm{a}}$ & $31^{\mathrm{a}}$ & $87^{\mathrm{a}}$ \\
\hline
\end{tabular}

\section{Heterotrophic plate count (HPC) bacteria}

Water samples taken from different streams of upper Awash River showed highly significant variation ( $\mathrm{p} \geq 0.05$ ) for Heterotrophic plate count. The highest HPC was observed in round four while the lowest HPC was observed in round one. Highest Heterotrophic plate count was observed from the water sample taken from site4(Aw4), followed by the water sample taken from site 1 (Aw1) and the lowest CFU was observed in Aw3.The heterotrophic bacteria isolated during the study consisted of pigmented (yellow, orange, pink and red) and non-pigmented (white) colonies. The high levels of HPC bacteria in the drinking water at Aw4may be due to different anthropogenic activities and wastes discharge in to the water channel in this site.

Table 5: Heterotrophic plate count $\mathrm{CFU} / \mathrm{ml}$

\begin{tabular}{|l|l|l|l|l|l|l|l|}
\hline organism & site & $\begin{array}{l}\text { CFU/ml } \\
\text { Round 1 }\end{array}$ & $\begin{array}{l}\text { CFU/ml } \\
\text { Round 2 }\end{array}$ & $\begin{array}{l}\text { CFU/ml } \\
\text { Round 3 }\end{array}$ & $\begin{array}{l}\text { CFU/ml } \\
\text { Round 4 }\end{array}$ & $\begin{array}{l}\text { CFU/ml } \\
\text { Round 5 }\end{array}$ & $\begin{array}{l}\text { CFU/ml } \\
\text { Round 6 }\end{array}$ \\
\hline \multirow{5}{*}{ HPC } & Aw1 & $900^{\mathrm{d}}$ & $980^{\mathrm{d}}$ & $990^{\mathrm{d}}$ & $1100^{\mathrm{d}}$ & $1900^{\mathrm{d}}$ & $1790^{\mathrm{d}}$ \\
\cline { 2 - 8 } & Aw2 & $720^{\mathrm{c}}$ & $730^{\mathrm{b}}$ & $890^{\mathrm{c}}$ & $980^{\mathrm{c}}$ & $1340^{\mathrm{c}}$ & $1290^{\mathrm{c}}$ \\
\cline { 2 - 8 } & Aw3 & $350^{\mathrm{a}}$ & $520^{\mathrm{a}}$ & $410^{\mathrm{a}}$ & $310^{\mathrm{a}}$ & $730^{\mathrm{a}}$ & $530^{\mathrm{a}}$ \\
\cline { 2 - 8 } & Aw4 & $960^{\mathrm{e}}$ & $1100^{\mathrm{e}}$ & $1110^{\mathrm{e}}$ & $990^{\mathrm{c}}$ & $2320^{\mathrm{e}}$ & $2380^{\mathrm{e}}$ \\
\cline { 2 - 7 } & Aw5 & $430^{\mathrm{b}}$ & $860^{\mathrm{c}}$ & $470^{\mathrm{b}}$ & $610^{\mathrm{b}}$ & $980^{\mathrm{b}}$ & $880^{\mathrm{b}}$ \\
\hline
\end{tabular}

\section{Bacillus}

Water samples taken from different site of streams of upper Awash River showed significant differences for the Bacillus spp count. The highest Bacillus spp count was observed in round five and the lowest bacillus spp was observed in round one. The highest Bacillus spp count was recorded from the water sample taken from the site 4(Aw4) followed by the water sample taken from site1 (Aw1). The lowest Bacillus spp count was observed in the water samples taken from site 3 (Aw3).

Table6: Bacillusspp count $\mathrm{CFU} / \mathrm{ml}$

\begin{tabular}{|l|l|l|l|l|l|l|l|}
\hline Organism & Site & $\begin{array}{l}\text { CFU/ml } \\
\text { Round 1 }\end{array}$ & $\begin{array}{l}\text { CFU/ml } \\
\text { Round 2 }\end{array}$ & $\begin{array}{l}\text { CFU/ml } \\
\text { Round 3 }\end{array}$ & $\begin{array}{l}\text { CFU/ml } \\
\text { Round 4 }\end{array}$ & $\begin{array}{l}\text { CFU/ml } \\
\text { Round 5 }\end{array}$ & $\begin{array}{l}\text { CFU/ml } \\
\text { Round 6 }\end{array}$ \\
\hline \multirow{5}{*}{ Bacillus } & Aw1 & $560^{\mathrm{c}}$ & $730^{\mathrm{d}}$ & $540^{\mathrm{b}}$ & $670^{\mathrm{d}}$ & $990^{\mathrm{d}}$ & $790^{\mathrm{c}}$ \\
\cline { 2 - 8 } & Aw2 & $470^{\mathrm{b}}$ & $610^{\mathrm{c}}$ & $500^{\mathrm{b}}$ & $620^{\mathrm{c}}$ & $710^{\mathrm{b}}$ & $550^{\mathrm{b}}$ \\
\cline { 2 - 8 } & Aw3 & $320^{\mathrm{a}}$ & $320^{\mathrm{a}}$ & $420^{\mathrm{a}}$ & $390^{\mathrm{a}}$ & $490^{\mathrm{a}}$ & $470^{\mathrm{a}}$ \\
\cline { 2 - 8 } & Aw4 & $590^{\mathrm{c}}$ & $700^{\mathrm{d}}$ & $660^{\mathrm{c}}$ & $940^{\mathrm{e}}$ & $840^{\mathrm{c}}$ & $910^{\mathrm{d}}$ \\
\cline { 2 - 7 } & Aw5 & $330^{\mathrm{a}}$ & $460^{\mathrm{b}}$ & $430^{\mathrm{a}}$ & $510^{\mathrm{b}}$ & $530^{\mathrm{a}}$ & $580^{\mathrm{b}}$ \\
\hline
\end{tabular}




\section{Staphylococcus aureous}

The water samples taken from different sites of the upper Awash River showed significant differences for the count of Staphylococcus. The highest staphylococcus aureous was observed in round six and the lowest Staphylococcus aureous was observed in round one. The highest Staphylococcus count was observed from the water sample taken from site $4(\mathrm{Aw} 4)$ and the mean value range from $580 \mathrm{CFU} / \mathrm{ml}$ to $1950 \mathrm{CFU} / \mathrm{ml}$. the lowest Staphylococcus count was observed from the water sample taken from the site 3 (Aw3) and the mean value range from $300 \mathrm{CFU} / \mathrm{ml}$ to $800 \mathrm{CFU} / \mathrm{ml}$. Figure 2 indicates the picture of the different bacterial isolated colony and light microscope photo of the bacillus and Staphylococus spp

Table 13: StaphylococcusCFU/ml

\begin{tabular}{|l|l|l|l|l|l|l|l|}
\hline Organism & Site & $\begin{array}{l}\text { CFU/ml } \\
\text { Round 1 }\end{array}$ & $\begin{array}{l}\text { CFU/ml } \\
\text { Round 2 }\end{array}$ & $\begin{array}{l}\text { CFU/100ml } \\
\text { Round 3 }\end{array}$ & $\begin{array}{l}\text { CFU/100ml } \\
\text { Round 4 }\end{array}$ & $\begin{array}{l}\text { CFU/100ml } \\
\text { Round 5 }\end{array}$ & $\begin{array}{l}\text { CFU/100ml } \\
\text { Round 6 }\end{array}$ \\
\hline \multirow{5}{*}{$\begin{array}{l}\text { Staphyloc } \\
\text { occus }\end{array}$} & Aw1 & $730^{\mathrm{e}}$ & $910^{\mathrm{d}}$ & $560^{\mathrm{b}}$ & $1020^{\mathrm{e}}$ & $690^{\mathrm{c}}$ & $2640^{\mathrm{c}}$ \\
\cline { 2 - 7 } & Aw2 & $520^{\mathrm{c}}$ & $760^{\mathrm{b}}$ & $670^{\mathrm{c}}$ & $790^{\mathrm{c}}$ & $1990^{\mathrm{e}}$ & $1930^{\mathrm{b}}$ \\
\cline { 2 - 8 } & Aw3 & $300^{\mathrm{a}}$ & $530^{\mathrm{a}}$ & $380^{\mathrm{a}}$ & $460^{\mathrm{b}}$ & $320^{\mathrm{a}}$ & $800^{\mathrm{a}}$ \\
\cline { 2 - 8 } & Aw4 & $580^{\mathrm{d}}$ & $840^{\mathrm{c}}$ & $860^{\mathrm{d}}$ & $940^{\mathrm{d}}$ & $1690^{\mathrm{d}}$ & $1950^{\mathrm{b}}$ \\
\cline { 2 - 8 } & Aw5 & $370^{\mathrm{b}}$ & $490^{\mathrm{a}}$ & $360^{\mathrm{a}}$ & $400^{\mathrm{a}}$ & $610^{\mathrm{b}}$ & $770^{\mathrm{a}}$ \\
\hline
\end{tabular}

value followed with the same superscript letter are not significantly different from each other $(\mathrm{p} \geq 0.05)$
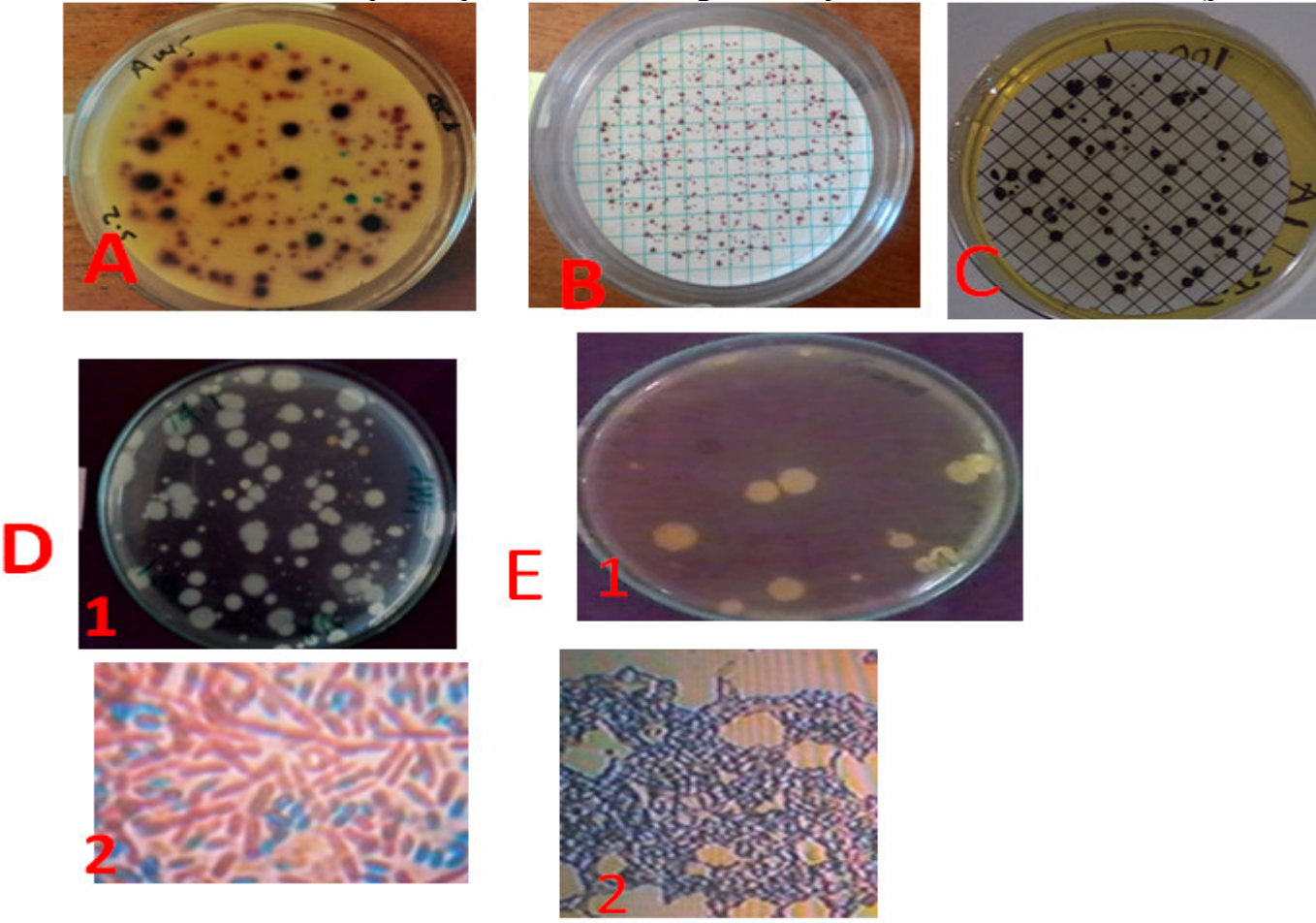

Fig2: The different indicator microorganisms isolated in this investigations A) coloforms and E.coli.; B) Entrococcus, C) Clostridium prefringins, 1D ) hetrotrophic plate count, 2) Endospore of Bacillus spp, E)1, staphylococcus isolate; 2, Gram reaction of Staphylococcus

\section{Discussion}

The results of this study indicated that, the count of total coliform for three month from five sampling sites indicate that sampling sites Aw1 and Aw4 showed higher total coliform ranged from 1780CFU/100ml to 17300 $\mathrm{CFU} / 100 \mathrm{ml}$ and $2050 \mathrm{CFU} / 100 \mathrm{ml}$ to $22000 \mathrm{CFU} / 100 \mathrm{ml}$ respectively. This is in line with the reports of Mohammed Yasin et al., (2015), which indicated that all water samples collected from unprotected water sources in Jima zone were positive for total coliforms and fecal coliforms (FC). And FC was detected in $80 \%$ of the total samples with counts ranging between 0.67 and $266.67 \mathrm{CFU} / 100 \mathrm{ml}$ although $66.67 \%$ of tap water samples were negative for FC.Reportes from the study of Rural Communities of Dire Dawa Administrative Council indicated that, about $83.34 \%$ of the water sample was positive for indicator bacteria (Desalegn Amenu etal.2012).The similarities this indicator microorganisms count may be due to the fact that all the water sources were unprotected as well as untreated, from the all sampling round, round one has highest load and round two has the lowest load, for E.coli count in the water sample taken from Aw3:11300 CFU/100ml and lowest in the water sample taken from site AW5: $200 \mathrm{CFU} / 100 \mathrm{ml}$.This result is in agreement with the report ofAbebe Berhanu and Dejene Hailu (2015) 
who investigated, Bacteriological and Physicochemical Quality of Drinking Water Sources and Household Water Handling Practice Among Rural Communities of Bona District, Sidama Zone-Zouthern, Ethiopia. According to these authors, majority ( $86 \%$ ) of the protected springs and wells in the study area did not fulfill the WHO's criteria for drinking water quality standards. Water schemes with high sanitary risk scores had high number of E. coli/100 $\mathrm{ml}$ of sample water. Highest Enterococcus count was observed in the water samples taken from the site 4(Aw4) and followed by the water sample taken from site 1 (Aw1), and the mean values were between $178 \mathrm{CFU} / 100 \mathrm{ml}$ to $2300 \mathrm{CFU} / 100 \mathrm{ml}$ and $218 \mathrm{CFU} / 100 \mathrm{ml}$ to $2270 \mathrm{CFU} / 100 \mathrm{ml}$ respectively. The lowest Enterococcus count was observed in the water samples taken from site 5 (Aw5). Enterococci are frequently isolated in soil, plants, vegetables (Facklam, and Teixeira, . 1997), in a variety of small-scale cheeses produced from cow, goat and buffalo milk (Andrighetto, et al., 2001)and in various foods (Franz, et al., 19990). Because of their high concentration in feces and their long survival in the environment, enterococci have been proposed as water fecal contamination indicators (US EPA 1986; Chenoweth, and Schaberg,1990). Epidemiological studies have indeed demonstrated a strong correlation between the presence of enterococci in water and disease risk (Kayet al. 1994). The highest Clostridium perfringes was detected from the water sample taken from site 2(Aw2) which was ranged between $201 \mathrm{CFU} / 100 \mathrm{ml}$ to $66 \mathrm{CFU} / 100 \mathrm{ml}$ and the lowest Clostridium perfringes counted was observed in water samples taken from site(Aw3) which was ranged $23 \mathrm{CFU} / 100 \mathrm{ml}$ to $95 \mathrm{CFU} / 100 \mathrm{ml}$. Clostridium perfringes (CP) is an anaerobic, Gram-positive, rod-shaped bacillus which produces spores. Obligate anaerobic bacteria cannot tolerate oxygen and die in the presence of oxygen (Willey et al., 2008).Clostridium perfringes can have serious health impacts on humans including gangrene and gastrointestinal disease. Highest Heterotrophic plate count was observed from the water sample taken from site4 (Aw4), followed by the water sample taken from site 1 (Aw1) and the lowest CFU was observed in Aw3.The heterotrophic bacteria isolated during the study consisted of pigmented (yellow, orange, pink and red) and non-pigmented (white) colonies, (Carter et al., 2000) isolated pigmented and non-pigmented colonies (especially yellow and orange colonies) in drinking water are an indication of a change in the water quality. Divekulu Siyum and DelelegnWoyessa (2013) reported, the mean cfu/ml of aerobic mesophilic bacteria (AMB) was 815.4; while the mean cfu/ml was 264 and 306.8 for coliforms and enterobacteriaceae, respectively. The isolated colonies also displayed diverse morphological and biochemical features. The highest Bacillus spp count was observed in round five and the lowest Bacillus spp was observed in round one. The highest Bacillus spp count was recorded from the water sample taken from the site 4(Aw4) followed by the water sample taken from site1 (Aw1). The lowest Bacillus spp count was observed in the water samples taken from site 3 (Aw3). The highest Staphylococcus aureous was observed in round six and the lowest Staphylococcus aureous was observed in round one. The highest Staphylococcus count was observed from the water sample taken from site 4(Aw4)and the mean value range from $580 \mathrm{CFU} / \mathrm{ml}$ to $1950 \mathrm{CFU} / \mathrm{ml}$. the lowest Staphylococcus count was observed from the water sample taken from the site 3 (Aw3) and the mean value range from $300 \mathrm{CFU} / \mathrm{ml}$ to $800 \mathrm{CFU} / \mathrm{ml}$. Adegboyega et al. 2015 reported that the bacteriological parameters analysed were total viable count which had values ranging from $2.02 \times 102$ to $6.08 \times 103 \mathrm{cfu} / \mathrm{ml}$. Bacteria isolates were identified as Bacillus sp, Escherichia coli, Pseudomonas sp, Salmonela spp, Aeromonas spp and Vibrio cholera. The fact that, about $83.34 \%$ of the water sample was positive for indicator bacteria shown that the three selected Peasant Association had risk of contamination. High concentration of microbiological indicators in all water sources of this study area have demonstrated the presence of pathogenic organisms which constitute a threat to anyone consuming or in contact with these waters. (Desalegn Amenu et al., 2012). The majority of the drinking water sources is either of unacceptable quality or grossly polluted.

\section{Conclusions}

The bacteriological quality of most water samples analyzed in the current study did not meet the standards set for drinking water. The total colifrom bacteria, E.coli, Entrococcus, Clostriuduim prifringens, heteroptrophic count and Staphylococcus aurous count where by far higher than the WHO criteria for the different water uses. Thus, with the current high dependence on alternative water sources other than tap water, it calls for awareness development on hygienic handling of spring and streams besides designing protections and regular purification strategies by the concerned bodies.

\section{References}

Abebe Berhanu and DejeneHailu2015. Bacteriological and Physicochemical Quality of Drinking Water Sources and Household Water Handling Practice Among Rural Communities of Bona District, Sidama Zone-Zouthern, Ethiopia. Science Journal of Public Health 3(5):782-789.

Adegboyega A.M, Olalude C.B And Odunola O.A 2015 Physicochemical and Bacteriological Analysis of Water Samples Used For Domestic Purposes in Idi Ayunre, Oyo State, Southwestern Nigeria. IOSR Journal of Applied Chemistry (IOSR-JAC) Volume 8, Issue 10.PP 46-50

Amangabara, G.T., Ejenma, E., 2012. Groundwater quality assessment of Yenagoa and environs and Duerden, B.I., Eds.), 9th Edn, pp. 669-682. Edward Arnold, London, UK. 
APHA/AWWA/WEF, 1998. Standard Methods for the Examination of Water and Wastewater. 20th Edition. American Public Health Association, Washington, DC.

Andrighetto, C., Knijff, E., Lombardi, A., Torriani, S., Vancanneyt, M., Kersters, K., Swings, J. and Dellaglio, F.J. (2001)] Franz, C.M.A.P., Holzapfel, W.H. and Stiles, M.E. (1999) Enterococci at the crossroads of food safety. Int. J. Food

Bagshaw, C. S. (2002). Factors influencing direct deposition of cattle fecal material in riparian zones. MAF technical paper no: 2002/19. University of Auckland, Department of Psychology. Wellington, New Zealand

Birtukan Getahun, FelekeMoges and BerhanuAndualem (2014). Physico-Chemical and Bacteriological Quality of Water from Different Sources in Gondar Town, World Applied Sciences Journal 32 (9): 1800-1807 Building priorities for Ethiopia, Proceedings of MOWR/EARO/IWMI/ILRI

Chenoweth, C. and Schaberg, D. (1990) The epidemiology of enterococci. Eur. J. Clin. Microbiol. Infect. Dis. 9, $80-89$.

DesalegnAmenu, SissayMenkir and TesfayeGobena ( 2012) Microbiological Quality of Drinking Water Sources in Rural Communities of Dire Dawa Administrative Council STARS Journals 1(4): 33-37

Desalegn Amenu1*, Sissay Menkir2 and Tesfaye Gobena3 Microbiological Quality of Drinking Water Sources and Water Handling Practices among Rural Communities of Dire Dawa Administrative Council Int. J . Current Res.Acd. Rev.1(2):29-54

Divekulu Siyum and Delelegn Woyessa (2013) Assessment of bacteriological quality and traditional treatment method of water borne disease.

EPA (2002). US Environment protection agency, safe drinking water act amendment.

Facklam, R.R. and Teixeira, L.M. (1997) Enterococcus In: Topley and Wilsons Microbiology and Microbial Infections (Balows, A.

Falkenmark M.(Ed.), Rural Water and Health. Scandinavian Institute of African Studies, Uppsala, 1982;75-83.

Federal Democratic Republic of Ethiopia, Ministry of Water Resources (FDRE, MWR) (2002).

Ethiopian guidelines specification for drinking water quality. Federal Democratic Republic of Ethiopia, Ministry of Water Resorces, Addis Ababa, Ethiopia.

Fewtrell, L. and Colford, J. (2004). Water, Sanitation and Hygiene: Interventions and Diarrhoea a Systematic Review and Meta-analysis. The International Bank for Freeze, R.A., Cherry, J.A., 1979. Groundwater. Prentice-Hall Inc., New Jersey, pp. 604.

Fujioka, R. S., and L. K. Shizumura(1985). Clostridium perfringens: a reliableindicator of stream water quality. J. Water Pollut. Control Fed. 57:986-992.

GetachewBegashaw (2002). Integrated water and land management research and capacity

Hrudey SE, Hrudey EJ: Published case studies of waterborne disease outbreaks-evidence of a recurrent threat. Water Environ Res 2007, 79:233-245. International workshop held at ILRI, Addis Ababa, Ethiopia.

Jones AQ, Majowicz SE, Edge VL, Thomas MK, MacDougall L, Fyfe M, Atashband S, Kovacs SJ: Drinking water consumption patterns in British Columbia: an investigation of associations with demographic factors and acute gastrointestinal illness. Sci Total Environ 2007, 388:54-65.

Kay, D., Fleisher, J.M., Salmon, R.L., Jones, F., Wyer, M.D., Godfree, A.F., Zelenauch-Jacquotte, Z. and Shore, R. (1994)] US EPA (1986) Bacteriological Ambient Water Quality Criteria for Marine and Freshwater Recreational Waters. PB86-158-045.

Marshall JK, Thabane M, Garg AX, Clark WF, Salvadori M, Collins SM, The Walkerton Health Study Investigators: Incidence and epidemiology of irritable bowel syndrome after a large waterborne outbreak of bacterial dysentery. Gastroenterology 2006, 131:445-450. Microbiol. 47, 1-24.

Milkiyas Tabor1, MulugetaKibret, BayehAbera (2011). bacteriological and physicochemical Quality of drinking water and hygiene-sanitation practices of the consumers in Bahir Dar City, Ethiop J Health Sci. Vol.21, No.1; $19-26$

Mohammed Yasin, T Ketema, K Bacha (2015). Physico-chemical and bacteriological quality of drinking water of different sources, Jimma zone, Southwest Ethiopia8:541. Department of Biology, College of Natural Sciences, Jimma University, P. O. Box 378, Jimma, Ethiopia

Mohammed Yasin, TsigeKetema and KetemaBacha* 2015 Physico-chemical and bacteriological quality of drinking water of different sources, Jimma zone, Southwest Ethiopia.BMC Res Notes 8:541: 1-13

Peace T, Mazumder A: Tracking patterns of enteric illnesses in populations and communities. Environ Health Percept 2007, 115:58-64 Phenotypic and genetic diversity of enterococci isolated from Italian cheeses. Dairy Res. 68, 303-316.

Prabu, P. C., Wondimu, L., \&Tesso, M.(2010).Assessment of water quality of Huluka river and Aleltu river of Ambo ,Ethiopia.J,Agr.Tech.13:131-138 Predicting likelihood of gastroenteritis from sea bathing: results from randomised exposure. Lancet 344, 905-909.

Reagen PA and Bookins-Fisher J. In: Community health in the 21 st century. Water quality. Masssachussets, Allyn and Bacon, 1997;439-62. Reconstruction and Development / World Bank. www.worldbank.org 
Shamsuddeen U, Bukar A, Usman AD, Kabir MH, Abdulmalik (2010). Bacteriological quality of water used for ice making in some parts of Kano metropolis, Nigeria. Bayero J Pure Appl Sci. 2010;3:199-20

Srinivasa moorthy, K., Vasanthavigar, M., Chidambaram, S., Anandhan, P., Manivannan, R.,Stein, E. D., Tiefenthaler, L. L., \& Schiff, K. C. (2007). Sources, patterns and mechanisms of storm water pollutant loading from watersheds and land uses of the greater Los Angeles area, California, USA. Technical Report 510. Southern California Coastal Water Research Project. Costa Mesa, CA, March 2007, pp. 77

Tariq, S. Sudha and A.L. Reyaz (2016). Isolation and Screening of Bacillus Species from Sediments and Application in Bioremediation Int.J.Curr. Microbial.App.Science (2016) 5(6): 916-924

Teka Gebre-Emanuel. Environmental Health: Water supply \& Sanitation Status in Ethiopia. Issues \& constrains. 1991;6-10. United States Environmental Protection Agency, Springfield, VA.

US EPA, 1986. Ambient water quality criteria for bacteria. USEPA, Washington, D.C. EPA 440/5/84-002.

US EPA, 2002. Implementation guidance for ambient water quality criteria for bacteria. USEPA, Washington, DC.EPA-823-B-02-003.

Well water users in jimma town, southwest ethiopia . ARPN Journal of Agricultural and Biological Science VOL. 8, NO. 6, 477-486

White G. (Ed.), Water, Health and Society. Selected works by Abel Wolman. Indiana university press, $1969: 32$. 14. Ethiopian Federal Democratic Republic's Water Resources Policy. Ministry of Water Resources, Addis Abeba, May 1997.

World Health Organization (WHO) (2003). Guide lines for drinking water quality, Vol.3. World Health Organizations, Switzerland, Geneva.

World Health Organization (WHO) (2004). Water, sanitation and hygiene links to health, facts and figures. sGeneva 